\title{
Analisis Diterminan Ketimpangan Wilayah di Provinsi Jambi Pada Periode Tahun 2008 - 2013
}

Oleh:

\section{*) Adi Putra \\ **) Sekolah Tinggi IImu Ekonomi Muhammadiyah Jambi}

\begin{abstract}
Abstrak
Penelitian ini berupaya untuk dapat memetakan willyah Kabupaten Kota yang ada di Provinsi Jambi serta untuk melihat apakah factor Biaya Modal/Pengeluaran Pemerintah, Investasi dan Tenaga Kerja merupakan factor yang dominan yang dapat menyebakan terjadinya ketimpangan pembangunan di wilayah-wilayah tersebut. Data yang diperoleh dianalisis secara deskriptip dan juga menggunakan Tipologi Klasen. Hasil penelitian menunjukan bahwa memang factor seperti Biaya Modal/Pengeluaran Pemerintah, Investasi dan Tenaga Kerja merupakan faktor yang Signifrkan mempengaruhi Terjadinya Ketimpangan Pembangunan Wilayah Kabupaten Kota di Provinsi Jambi.
\end{abstract}

Kata Kunci : Ketimpangan Wilayah, Tipologi Klasen

\section{PENDAHULUAN}

Otonomi daerah memberikan kewenangan yang luas kepada daerah sehingga memungkinkan daerah untuk dapat lebih leluasa dan fleksibel dalam menentukan arah pcmbangunan di daerah sesuai dengan potensi, kondisi dan aspirasi yang berkembang dimasyarakat. Undang-undang Nomor 33 Tahun 2004 tentang perimbangan keuangan antara Pemerintah Pusat dan Pemerintah Daerah sebagai revisi terhadap UU No 25 Tahun 1999. Telah memberi kewenangan yang luas kepada pemerintah daerah untuk mengelola keuangan yang baik dan proporsional, sehingga Pemerintah Daerah dapat melakukan berbagai akselerasi pembangunan di daerah karena memilki kewenangan tersebut.

Tantangan pembangunan Provinsi Jambi yang dihadapi, terutama dalam 20 tahun mendatang serta pertimbangan modal dasar yang dimiliki dan amanat pembangunan daerah yang tertuang dalam Visi dan Misi Pembangunan Provinsi Jambi Tahun 2005-2025, maka pertu memperhatikan Indicator-indicator ekonomi yang salah satunya adalah pendapatan Perkapita (GNP atau PDB).

Data BPS Produk Domestik Bruto (PDB) Provinsi Jambi dari tahun 2008 hingga tahun 3913 rata-rata pertumbuhannya 7,8 persen pertahun. Sedangkan Pertumbuhan PDRB wilayah wilayah Kabupaten/Kota di Provinsi Jambi pada tahun 2013 masing- masing kabupaten Kerinci 6,44 persen, Merangin 6,45 persen, Sarolangun, 7,77 persen, Batang Hari 
6,84 persen, Muaro Jambi 7,69 persen, Tanjung Jabung Timur 4,09 persen, Tanjung Jabung Barat 7,55 persen, Tebo 6,51 persen, Muara Bungo 7,48 persen, Kota Jambi 7,76 persen dan Kota Sungai Penuh 6, 92 persen.

Ketidaksamaan potensi yang dimiliki antar wilayah kabupaten/ Kota tersebut menyebabkan akan terjadinya perbedaan Pendapatan Asli Daerah, disparitas pertumbuhan ekonomi serta. ketimpangan pembangunan antar wilayah. Konsentrasi kegiatan ekonomi yang tinggi di daerah tertentu merupakan salah satu faktor yang menyebabkan terjadinya ketimpangan pembangunan antar daerah. Ekonomi dari daerah dengan konsentrasi tinggi cenderung tumbuh pesat dibandingkan daerah yang tingkat konsentrasi ekonomi rendah cenderung mempunyai tingkat pembangunan dan pertumbuhan ekonomi yang lebih rendah.

\section{TELAAH PUSTAKA}

\section{Pembangunan Wilayah}

Pembangunan wilayah mendukung pembangunan nasional demikian sebaliknya, Pembangunan wilayah dimanapun tujuannya hanya satu yaitu kesejahteraan dan kemakmuran takyat Bila membahas tentang pembangunan, maka terlebih dahulu harus dimengerti pengertian wilayah. Hal ini dikarenakan program pembangunan berhubungan dengan berkembangnya fungsi di suatu unit kawasan. wilayah berarti suatu kawasan ruang dipermukaan bumi.

Wilayah dapat didefinisikan dalam beberapa hal. Wilayah yaitu salah satu unit dari geografi dan Para ahli geografipun memandang wilayah adalah tiap bagian yang ada di permukaan bumi. Menurut (Lireza P. 2010) wilayah merupakan bagian permukaan yang memiliki batasan batasan tertentu aspek fisik dan aspek sosial budaya merupakan dua hal yang mcmpengaruhi karakteristik wilayah.

Ditinjau dari konsep nomenklatur kewilayahan, wilayah ( region ) merupakan istilah dwi wilayah ataupun kawasan. Wilayah merupakan ruang yang manadari sudut pandang pengertiannya terbagi atas tiga, yaitu :

a. Wilayah homogen adalah suatu ruang yang di dalamnya terdapat aktivitas ekonomi dan memiliki kesamaan sifat baik itu dari segi pendapatan Perkapita, geografis, social budaya, dan sifat lainnya.

b. Wilayah modal merupakan ruang ekonomi yang didominasi oleh kegiatan ekonoomi sentral. 
c. Wilayah administrasi/perencanaan, yaitu ruang ekonomi yang berada di bawah administrasi provinsi, kabupaten, kotamadya, ataupun kecamatan.

Dalam hal penelitian pembangunan, pengertian yang ketiga lebih sering digunakan hal ini didukung dengan pengertian istilah wilayah secara geografis oleh (Rustiadi, 2009), wilayah adalah bagian geografis yang mempunyai spesifik batasan dan saling berhubungan baik secara fungsional maupun non fungsional.

Pada umumnya pembangunan adalah kegiatan dalam proses yang dilakukan dengan sadar dan terencana untuk menuju perubahan yang lebih baik. Pembangunan menyebabkan terjadinya pertumbuhan dan pertumbuhan akan terjadi sebagai akibat adanya pembangunan dengan demikian pembangunan tidak lepas dari pertumbuhan baik itu berupa pengembangan/perluasan (expansion) atau peningkatan (improvement) dari aktivitas yang dilakukan.

Menurut Siagian, 2009 pengertian-pembangunan Pembangunan adalah suatu perubahan untuk menjadi lebih baik dari kondisi sekarang, bila pembangununan sebagai pertumbuhan berarti menunjukkan perkembangan secara berkelanjutan baik kualitatif maupun kuantitatif. Usaha dalam rangka menunjang kesjahteraan masyarakat baik dalam bidang ekonomi maupun sosial bertujuan untuk mengurangi kemiskinan tanpa merusak lingkungan atau kehidupan sosial demi peningkatan kualitas manusia disebut dengan pembangunan.

Sedangkan (Joko, 2012) Pembangunan itu pertumbuhan ekonomi yang disertai dengan perubahan struktur ekonomi dan aktivitas ekonomi maupun peningkatkan pendapatan per kapita disebut dengan pembangunan. Peningkatan yang terus menerus pada Gross Domestic Product atau Produk Domestik Bruto suatu negara. Maupun Produk Domestik Regional Bruto (PDRB) suatu provinsi, kabupaten, atau kota juga diartikan sebagai pembangunan.

(Kuncoro, 2009). Makna pembangunan bagi wilayah yang tradisional difokuskan pada PDRB suatu provinsi, kabupaten dan kota. Ditinjau dari pendapat tersebut, maka pembangunan wilayah memiliki arti yang luas mencakup pembangunan berbagai aspek terutama aspek ebonomi.

Pembangunan aspek ekonomi didefinisikan (Sukirno,1999) sebagai proses untuk meningkatkan pendapatan Perkapita penduduk dalam waktu jangka panjang. Dari penjelasan di atas terlihat bahwa pembangunan memiliki sifat-sifat sebagai berikut : 
a. Mengakibatkan terjadinya perubahan secara kontinue

b. Bertujuan untuk menaikkan pendapatan Perkapita terus menerus dalam jangka panjang

c. Meningkatkan kesejahteraan masyarakat

\section{Klasifikasi Wilayah}

Secara umum pengembangan wilayah merupakan keterpaduan semua program dari keseluruhan kegiatan yang memberi kontribusi untuk pembangunan wilayah dengan mempertimbangkan ketersediaan sumber daya. Aswandi (2002) memiliki pemikiran yang mana membagi wilayah per kabupaten menjadi empat golongan yaitu :

a. Kabupaten cepat maju dan cepat tumbuh (high growth and high income),

b. Kabupaten maju tapi tertekan (high income but low growth),

c. Kabupaten berkembang cepat (high growth but low income)

d. Kabupaten relatif tertinggal ( low growth and low income),

Tiap wilayah dapat berkembang dan tumbuh dikarenakan memiliki potensi serta dapat berkoordinasi dan bekerjasama yang baik, akan tetapi bila tidak memiliki potensi ataupun tidak bisa bekerjasama maka kemajuan wilayah tersebut akan dipenuhi dengan polemik bahkan dapat menjadi wilayah tertinggal. Frances Stewart dan Paul Streeten dalam buku Amri Amir (2007) menjelaskan bahwa pembangunan memiliki dua strategi yang mana strategi tersebut diambil berdasarkan atas tujuan yang ingin dicapai,yaitu :

a. Penghapusan kemiskinan

b. Pengurangan ketimpangan

Dari penjelasan di atas dapat dikatakan konsep pengembangan wilayah, yaitu strategi yang mengimbangi penggunaan sumberdaya agar pembangunan antar sektor antar wilayah dm pelaku pembangunan sejalan demi mewujudkan tujuan pembangunan wilayah. Sebelum menetapkan strategi pembangunan, maka perlu dibuat kebijakann pembangunan yang mana memperhatikan karekteristik wilayah. Karekteristik wilayah dibagi menjadi empat bagian,

a. Wilayah maju bercirikan sebagai pusat pertumbuhan karena tempat sentral kegiatan

b. Wilayah sedang berkembang memiliki sumber daya alam dan potensi tinggi

c. Wilayah belum berkembang bercirikan terdapat banyaknya sumber daya alam yang belum dimanfaatkan 
d. Wilayah tidak berkembang merupakan wilayah yang tidak memiliki potensi apapun atau dieksploitasi oleh wilayah lain.

Menurut Rustiadi (2009) pembangunan wilayah memiliki dua kerangka konseptual, yaitu :

- Konsep basis ekonomi yang lebih terkenal dengan sebutan teori basis ekonomi, yaitu demand input dapat ditingkatkan dengan cara perluasan demand output.

- Konsep perbedaan tingkat imbalan (rate of return) yang menerangkan bahwa suatu wilayah akan menjadi keterbelakang bila produktifitasnya rendah. Konsep ini lebih memperhatikan lingkungan seperti prasarana untuk peningkatan produktifitas dibanding rasio modal-tenaga.

Untuk membangun wilayah dari hasil penelitian Nataluddin (2001) diketahui bahwa kemajuan pembangunan Provinsi Jambi tidak terlepas dari pemerintah pusat. Secara tonsepsional, pola hubungan antara Pemerintah pusat dengan pemerintah wilayah, harus dilakukan dengan kemampuan keuangan wilayah dalam membiayai pelaksanaan pemerintahan dan pembangunan, walaupun pengukuran kemampuan keuangan wilayah ini akan menimbulkan perbedaaan. Menurut EL Roy (2009) meskipun pembangunan dilaksanakan dengan percepatan namun, hingga saat ini tiap wilayah tetap mengalami permasalahan dibsrbagai aspek.

\section{Pertumbuban Ekonomi Wilayah}

Pertumbuhan ekonomi menurut Profesor Simon Kuznets adalah kenaikan jangka penjang dalam kemampuan suatu negara untuk menyediakan semakin banyak jenis barang-barang ekonomi bagi penduduknya. Kemampuan ini tumbuh sesuai dengan kemajuan teknologi, penyesuaian kelembagaan dan ideologis yang diperlukannya.(Jhingan, 2003).

Model pertumbuhan ini memandang bahwa rasio modal dan kapital (capital output ratio) bersifat dinamis dan cepat berubah. Sehingga untuk menciptakan output tertentu, dapat digunakan jumlah modal yang berbedabeda pula sesuai dengan kebutuhan. Jika lebih banyak modal yang digunakan (capital intensive) maka tenaga kerja yang diperlukan sedikit. Sebaliknya jika tenaga kerja yang dibutuhkan lebih banyak (labor intensive) maka modal yang dibutuhkan sedikit (Victor, 2005).

\section{Teori Pertumbuhan Klasik}

Jumlah penduduk, stok barang modal kekayaan alam dan teknologi merupakan faktor - faktor yang mempengaruhi pertumbuhan ekonomi. Akan tetapi, para ahli ekonomi klasik menitik 
beratkan pada pengaruh pertambahan penduduk. Salah satu tokoh teori klasik, yaitu Malthus berpendapat kenaikan modal dan keperluan hidup akan terlampaui jika pertumbuhan penduduk dibiarkan meningkat terus menerus.

Menurut teori klasik yang dikemukakan oleh Adam Smith suatu negara mengalami pertumbuhan ditandai dengan: 1. Pertumbuhan jumlah penduduk, dan 2 . Peningkatan output (GNP). Jumlah penduduk dianggap faktor yang pasif. Dengan demikian pertumbuhan suatu negara lebih tergantung pada pertumbuhan output (GNP). Sedangkan pertumbuhan output sangat tergantung kepada jumlah modal yang ditanam, modal ditentukan oleh jumlah laba yang diperoleh, laba tergantung kepada pasar (permintaan) dan permintaan tergantung pada jumlah penduduk dan penduduk tergantung pada upah, upah tergantung pada output.

\section{Teori Pertumbuhan Ekonomi Harrod - Domar}

Teori ini dibuat oleh Evsey Domar dan Sir Roy F. Harrod yang mempunyai asumsi sebagai berikut : Barang modal dan kegiatan perekonomian digunakan secara penuh oleh masyarakat, Sektor rumah tangga dan perusahaan merupakan sektor perekonomian, Tabungan proporsional dan pendapatan nasional sama besar, Rasio pertambahan modal output dengan kecendrungan menabung memiliki jumlah yang tetap.

Menurut Harrod-Domar, setiap perekonomian dapat menyisihkan suatu proporsi tertentu dari pendapatan nasionalnya Jika hanya untuk mengganti barang-barang modal yang rusak. Namun demikian untuk menumbuhkan perekonomian tersebut, diperlukan investasiinvestasi baru sebagai tambahan stok modal: Hubungan tersebut telah kita kenal dengan istilah rasio modal-output (COR). Dalarn teori ini disebutkan bahwa, jika ingin tumbuh, perekonomian harus menabung dan menginvestasikan suatu proporsi tertentu dari output totalnya. Semakin banyak tabungan dan kemudian di investasikan, maka semakin cepat perekonomian itu akan tumbuh (Lincolyn, 2004).

\section{Tiori Pertumbuhan Ekonomi Neo Klasdk Solow Swan}

Teori ini menjelaskan bagaimana tingkat tabungan dan investasi pertumbuhan populasi dan kemajuan teknologi mempengaruhi tingkat output perekonomian dan pertumbuhannya sepanjang waktu (Mankiw, 2000). Dalam teori ini perkembangan teknologi diasumsikan sebagai variabel yang eksogen.

Hubungan antara output, modal dan tenaga kerja dapat ditulis dalam bentuk fungsi sebagai berikut. $\mathrm{y}=\mathrm{f}(\mathrm{k})$ dimana output per pekerja (y) adalah fungsi dari capital stock per 
pekerja. Sesuai dengan fungsi produksi yang berlaku hukum "the law of deminishing return", dimana pada titik produksi awal, penambahan kapital per labor akan menambah output per pekerja lebih banyak, tetapi pada titik tertentu penambahan capital stock per pekerja tidak akan menambah output per pekerja dan bahkan akan bisa mengurangi output per pekerja.

Sedangkan fungsi investasi dituliskan sebagai berikut. $i=s$ f(k) Dalam persamaan tersebut, tingkat investasi per pekerja merupakan fungsi capital stock per pekerja.Capital stock sendiri dipengaruhi oleh besarnya investasi dan penyusutan dimana investasi akan menambah capital stock dan penyusutan akan menguranginya. $\Delta \mathrm{k}=\mathrm{i}-y \mathrm{kt}$, Dimana ; $y$ adalah porsi penyusutan terhadap capital stock.

Kemajuan teknologi dalam teori Solow dianggap sebagai faktor eksogen. Dalam perumusan selanjutnya fungsi produksi adalah $\mathrm{Y}=\mathrm{f}(\mathrm{K}, \mathrm{L}, \mathrm{E})$, dimana $\mathrm{E}$ adalah efisiensi tenaga kerja. Selanjutnya y adalah Y/LE dimana LE menunjukkan jumlah tenaga kerja efektif. Pengaruh dari kemajuan teknologi terhadap perubahan modal dapat dirumuskan sebagai $\Delta \mathrm{k}=\mathrm{sf}(\mathrm{k})-(\mathrm{Y}+\mathrm{n}+\mathrm{g}) \mathrm{kt}$, dimana g menggambarkan kemajuan teknologi melalui efisiensi tenaga kerja. Dampak dari kemajuan teknologi adalah dapat memunculkan pertumbuhan ekonomi secara berkelanjutan karena mengoptimalkan efisiensi tenaga kerja yang terus tumbuh.

Teori pertumbuhan ini menjelaskan tentang pertumbuhan region yang mengidentifikasi faktor utama pendukung pertumbuhan region, yaitu kemajauan teknologi, pertumbuhan modal dan pertumbuhan angkatan kerja.

\section{Pengeluaran Pemerintah}

Pengeluaran pemerintah dalam arti riil dapat dipakai sebagai indikator besarnya kegiatan pemerintah yang dibiayai oleh pengeluaran pemerintah. Semakin besar dan banyak kegiatan pemerintah semakin besar pula pengeluaran pemerintah yang bersangkutan. Dalam teori ekonomi makro, pengeluaran pemerintah terdiri dari tiga pos utama yang dapat digolongkan sebagai berikut : (Boediono,1999)

1) Pengeluaran pemerintah untuk pembelian barang, dan jasa.

2) Pengeluaran pemerintah untuk gaji pegawai. Perubahan gaji pegawai mempunyai pengaruh terhadap proses makro ekonomi, di mana perubahan gaji pegawai akan mempengaruhi tingkat permintaan secara tidak langsung. 
3) Pengeluaran pemerintah untuk transfer payment: Transfer payment bukan pembelian barang atau jasa oleh pemerintah dipasar barang melainkan mencatat pembayaran atau pemberian langsung kepada warganya yang meliputi misalnya pembayaran subsidi atau bantuan langsung kepada berbagai golongan rnasyarakat, pembayaran pensiun, pembayaran bunga untuk pinjaman pemerintah kepada masyarakat. Secara ekonomis transfer payment mempunyai status dan pengaruh yang sama dengan pos gaji pegawai meskipun secara administrasi keduanya berbeda.

Pengeluaran Pemerintah (goverment expenditure) adalah bagian dari kebijakan fiskal (Sadono Sukirno, 2000), yaitu suatu tindakan pemerintah untuk mengatur jalannya perekonomian dengan cara menentukan besarnya penerimaan dan pengeluaran pemerintah sdiap tahunnya, yang tercermin dalam dokumen Anggaran Pendapatan Belanja Negara (APBN) untuk nasional dan Anggaran Pendapatan Belanja Daerah (APBD) untuk daerah atau regional. Tujuan dari kebijakan fiskal ini adalah dalam rangka menstabilkan harga, tingkat output, maupun kesempatan kerja dan memacu atau mendorong pertumbuhan ekonomi.

Pendapat Keynes dalam Sadono Sukirno (2000) bahwa peranan atau campur tangan pcmerintah masih sangat diperlukan yaitu apabila perekonomian sepenuhnya diatur olah kegiatan di pasar bebas, bukan saja perekonomian tidak selalu mencapai tingkat kesemptan kerja penuh tetapi juga kestabilan kegiatan ekonomi tidak dapat diwujudkan. Akan tetapi fluktuasi kegiatan ekonomi yang lebar dari satu periode ke periode lainnya dan ini akan naaimbulkan implikasi yang serius kepada kesempatan kerja dan pengangguran dan tingkat harga. Menurut keynes salah satu unsur permintan agregat adalah pengeluaran pemerintah. Pengeluaran pemerintah secara umum dapat diketahui dengan membandingkan nilai $\mathrm{G}$ dan $\mathrm{Y}$, yang mana $\mathrm{G}$ merupakan penngeluaran pemerintah sedangkan $\mathrm{Y}$ pendapatan nasional dengan Pendekatan : $\mathrm{Y}=\mathrm{C}+\mathrm{I}+\mathrm{G}+\mathrm{X}-\mathrm{M}$. dari sini dapat diketahui seberapa besar pentingnya Pengeluaran pemerintah terhadap perekonomian nasional.

\section{Tenaga Kerja}

Produktivitas tenaga kerja merupakan perbandingan antara tingkat output yang dihasilkan dengan jumlah tenaga kerja. Adapun faktor - faktor yang dapat meninngkatkan produktivitas tenaga kerja antara lain pendidikan dan pelatihan, kebutuhan hidup dan perencanaan tenaga kerja. Di negara yang sedang berkembang tenaga kerja termasuk dalam faktor poduksi, karena penambahan tenaga kerja akan berpengaruh terhadap output 
(Manurung,2001). Menurut Ananta (1997) proses penggunaan sumber daya akan menyertai pertumbuhan ekonomi untuk meningkatkan kapasitas produksi yang terlihat pada :

a. Peningkatan kuantitas serta kualitas barang modal per tenaga kerja

b. Meningkatnya jumlah tenaga kerja yang trampil dan terdidik

c. Sarana dan prasarana penunjang semakin baik

\section{Investasi}

Berdasarkan teori ekonomi, investasi berarti pembelian (dan produksi) dari modal barang yang tidak dikonsumsi tetapi digunakan untuk produksi yang akan datang, (barang produksi). Investasi adalah suatu komponen dari $\mathrm{PDB}$ dengan rumus $\mathrm{PDB}=\mathrm{C}+\mathrm{I}+\mathrm{G}+(\mathrm{X}-$ M). Fungsi investasi pada aspek tersebut dibagi pada investasi non-residential (seperti, pabrik dan mesin) dan investasi residential (rumah baru). Investasi adalah suatu fungsi pendapatan dan tingkat bunga, dilihat dengan kaitannya $I=(Y, i)$. Suatu pertambahan pada pendapatan akan mendorong investasi yang lebih besar, dimana tingkat bunga yang lebih tinggi akan menurunkan minat untuk investasi sebagaimana hal tersebut akan lebih mahal dibandingkan dengan meminjam uang. Walaupun jika suatu perusahaan lain memilih untuk menggunakan dananya sendiri untuk investasi, tingkat bunga menunjukkan suatu biaya kesempatan dari investasi dana tersebut daripada meminjamkan untuk mendapatkan bunga. Menurut Samuelson dan Nordhaus (1996) investasi merupakan suatu hal yang penting dalam pembangunan ekonomi karena investasi dibutuhkan sebagai faktor penunjang didalam neningkatkan proses produksi. Investasi merupakan langkah awal mengorbankan konsumsi wtuk memperbesar konsumsi di masa yang akan datang. Selain itu, mendorong terjadinya akumulasi modal.

Menurut Suparmoko dan Irawan (2002) ada beberapa cara untuk meningkatkan investasi, diantaranya yaitu:

1. Meningkatkan tabungan dengan mengurangi konsumsi

2. Pemerintah menjual obligasi dengan bunga menarik sehingga masyarakat tertarik untuk membelinya

3. Pembatasan impor barang barang konsumsi bila memungkinkan membatasi barang barang kapital agar ada inovasi di dalam negeri

4. Mengadakan pinjaman luar negeri

5. Memperluas sektor perdagangan luar negeri dengan menaikkan "terms of trade" (Mardalena, 2009) 


\section{METODE ANALISIS DATA}

\section{Metode Penelitian}

Metode penelitian yang digunakan dalam penelitian ini adalah metode penelitian analisis dista sekunder. Sedangkan analisis data sekunder yang dimaksud adalah data yang dihimpun ini berbagai sumber seperti, Badan Pusat Statistik serta beberapa instansi terkait lainnya dan hasil - hasil penelitian sejenis.

\section{Jenis dan Sumber Data}

Data sekunder dihimpun melalui metode dokumentasi dari berbagai publikasi resmi dari instansi pemerintah dan swasta serta hasil-hasil penelitian, baik yang diterbitkan pada berbagai jurnal ilmiah maupun tidak.

\section{Alat Analisis}

Analisis data yang dilakukan dalam penelitian ini menggunakan analisa deskriftif dan kuantitatif. Analisa deskriftif dilakukan untuk mendapatkan gambaran yang realistis dan Attual dari objek yang akan diteliti. Fungsi analisis deskriptif adalah untuk memberikan gambaran umum tentang data yang telah diperoleh. Gambaran umum ini bisa menjadi acuan untuk melihat karakteristik data yang kita peroleh. Adapun analisis statistika deskriptif ini memiliki tujuan untuk memberikan gambaran (deskripsi) mengenai suatu data agar data yang tersaji menjadi mudah dipahami dan informatif bagi orang yang membacanya.

\section{Analisis Tipologi Klassen}

Semua wilayah melihat target ekonomi regional dari pertumbuhan ekonomi yang dipengaruhi oleh dua factor, yaitu ekonomi dan non ekonomi. Analisis Tipologi Klassen digunakan untuk mengetahui klasifikasi wilayah berdasarkan dua indikator utama, yaitu laju pertumbuhan ekonomi yang ditinjau dari produk domestik regional bruto dan pendapatan atau produk domestik regional bruto Perkapita wilayah. Dengan menentukan rata-rata pertumbuhan economi sebagai sumbu vertikal dan rata-rata Produk Domestik Regional Bruto (PDRB) Perkapita sebagai sumbu horisontal, wilayah dalam hal ini kabupaten/kota. Selain hal tersebut dapat juga digunakan pendekatan wilayah dengan membandingkan rata-rata laju patumbuhan ekonomi dan PDRB Perkapita suatu wilayah dengan rata-rata Provinsi Jambi (Sjafriza1, 2008).

Adapun kriteria yang digunakan, yaitu :Wilayah cepat maju dan tumbuh berarti pertumbuhan ekonomi dan pendapatan Perkapitanya lebih tinggi dari rata- rata Provinsi Jambi, Wilayah maju tapi tertekan berarti tingkat pertumbuhan ekonomi lebih rendah dari 
rata-rata Provinsi Jambi akan tetapi pendapatan Perkapitanya lebih tinggi, Wilayah berkembang dapat berarti tingkat pendapatan Perkapitanya lebih rendah dari rata-rata Provinsi Jambi akan tetapi tingkat pertumbuhannya tinggi, dan Wilayah relative tertinggal atau lambat maju berarti pendapatan Perkapita dan pertumbuhan ekonominya lebih rendah dari rata-rata Provinsi Jambi.

\section{Analisis Regresi Berganda}

Analisis Regresi Berganda (Ordinary Least Square) digunakan untuk menjawab lersoalan ke tiga dengan model:

$$
\operatorname{LnY}=\beta_{0}+\beta_{1}, \operatorname{Ln} \mathrm{INV}+\beta_{2} \operatorname{LnGov}+\beta_{3} \operatorname{Ln} \mathrm{TK}+\mathrm{e}
$$

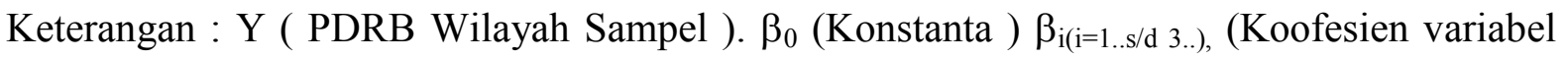
bebas), INV ( Investasi ), Gov (Pengeluaran Pemerintah) dan TK ( Tenaga Kerja )

\section{Uji Hipotesis}

Uji Hipotesis ini ini menggunakan uji simultan dan Uji Parsial. Uji simultan untuk menguji pengaruh dari variabel independen secara simultan terhadap variable dependent sedangkan Uji parrsial Uji-t dilakukan untuk mengetahui signifikansi setiap variable independen dalam aempengaruhi variable dependen dengan uji satu arah.

\section{HASIL DAN PEMBAHASAN}

Salah satu alat yang digunakan untuk mengukur tingkat kesejahteraan penduduk suatu daerah adalah PDRB Perkapita, dimana semakin besar PDRB Perkapita suatu daerah bisa diartikan semakin baik tingkat kesejahteraan masyarakat.

Tabel 1. Produk Domestik Bruto (PDRB) Provinsi Jambi ADHB dan ADHK

Periode Tahun 2008-2013

\begin{tabular}{|c|c|c|c|c|}
\hline \multirow{2}{*}{ Tahun } & \multicolumn{2}{|c|}{ ADHB } & \multicolumn{2}{c|}{ ADHB 2000 } \\
\cline { 2 - 5 } & $\begin{array}{c}\text { PDRB } \\
\text { (Juta Rupiah })\end{array}$ & $\begin{array}{c}\text { Pertumbuhan } \\
(\%)\end{array}$ & $\begin{array}{c}\text { PDRB } \\
\text { (Juta Rupiah })\end{array}$ & $\begin{array}{c}\text { Pertumbuhan } \\
(\%)\end{array}$ \\
\hline 2008 & 41.056 .484 & 0,00 & 15.297 .771 & 0,00 \\
2009 & 44.127 .006 & 7,48 & 16.274 .908 & 6,39 \\
2010 & 53.857 .688 & 22,05 & 17.471 .686 & 7,35 \\
2011 & 63.355 .314 & 17,63 & 18.963 .518 & 8,54 \\
2012 & 72.654 .165 & 14,68 & 20.373 .533 & 7,44 \\
2013 & 85.600 .00 & 17,83 & 21.980 .000 & 7,89 \\
\hline Rata-rata & 60.108 .443 & 13 & 18.393 .569 & 6 \\
\hline
\end{tabular}

Sumber : Data yang sudah diolah 
Dari tabel 1 terlihat bahwa PDRB Provinsi Jambi menurut harga berlaku selama tahun 2008-2013 terus mengalami pertumbuhan yang positif, dengan rata-rata pertumbuhan sebesar 13 persen setiap tahunnya. Laju pertumbuhan tertinggi pada tahun 2010 sebesar 22,05 persen. Sedangkan PDRB Provinsi Jambi menurut harga konstan selama tahun 20082013 juga terus mengalami pertumbuhan positif, dengan rata-rata pertumbuhan sebesar 6 persen setiap tahunnya. Sedangkan pertumbuhan PDRB ADHK tertinggi tercapai pada tahun 2011 sebesar pertumbuhan 8,54 persen.

Laju periumbuhan ekonomi Kabupaten/kota di Provinsi Jambi periode 2008-2013 ('Tabel 2 ) terlihat bahwa laju Pertumbuhan Ekonomi rata - rata tertinggi adalah Kota Jambi sebesar 7,76 persen Sedangkan pertumbuhan ekonomi terendah di Kabupaten Tanjung Jabung Timur sebesar 4,06 persen, namun bila dilihat dari rata - rata PDRB Perkapita Kabupaten /kota di Provinsi Jambi pada periode tahun 2008-2013 tersebut. Kota Jambi mempunyai PDRB Perkapita rata-rata tertinggi Rp. 3.320.414.000.000,- sedangkan PDRB Perkapita rata-rata terendah adalah pada Kota Sungai penuh dengan rata-rata sebesar Rp. 912.198.000.000,-. Dari hasil analisis Tipologi wilayah dapat terlihat seperti pada Tabel 2 dan 3 berikut.

Tabe1 2. PDRB Perkapita, Pertumbuhan Ekonomi dan Tipologi Klasen Dengan Pendekatan Wilayah di provinsi Jambi Tahun 2008- 2013

\begin{tabular}{|c|l|c|c|c|}
\hline NO & \multicolumn{1}{|c|}{ KABUPATEN } & $\begin{array}{c}\text { PDRB } \\
\text { (Perkapita } \\
\text { Rata-rata } \\
\text { (Rp. Juta) }\end{array}$ & $\begin{array}{c}\text { Laju } \\
\text { Pertumbuhan } \\
\text { PDRB 2008- } \\
\mathbf{2 0 1 3}(\%)\end{array}$ & Tipologi \\
\hline 1 & Kerinci & 1.271 .054 & 6,44 & 4 \\
2 & Merangin & 1.231 .533 & 6,45 & 4 \\
3 & Sarolangun & 1.437 .500 & 7,77 & 3 \\
4 & Batang Hari & 1.405 .884 & 6,86 & 3 \\
5 & Muaro Jambi & 1.317 .222 & 7,69 & 3 \\
6 & Tanjung Jabung Timur & 2.501 .828 & 4,06 & 2 \\
7 & Tanjung Jabung Barat & 2.493 .632 & 7,55 & 1 \\
8 & Tebo & 972.670 & 6,51 & 4 \\
9 & Muaro Tebo & 1.383 .553 & 7,48 & 3 \\
10 & Kota Jambi & 3.320 .414 & 7,76 & 1 \\
11 & Kota Sungai Penuh & 912.198 & 6,92 & 3 \\
\hline \multicolumn{2}{|r|}{ Rata-rata } & 1.658 .862 & 8,86 & \\
\hline
\end{tabular}

Sumber: data diolah 
Tabel 3. Klasifkasi Wilayah di Provinsi Jambi Tahun 2008-2013 berdasaran Pendekatan Tipologi Klassen

\begin{tabular}{|c|c|}
\hline Kuadran I & Kuadran II \\
Sektor Maju dan Tumbuh Cepat & Sektor Maju tetapi Tertekan \\
\hline $\begin{array}{c}\text { Kota Jambi dan } \\
\text { Tanjung Jabung Barat }\end{array}$ & Kab. Tanjung Jabung Timur \\
\hline Kuadran III & Kuadran IV \\
Sektor Berkembang Cepat & Sektor Relatif Tertinggi \\
\hline $\begin{array}{c}\text { Kab. Sarolangun, Kab., Batang Hari, } \\
\text { Kab. Muaro Jambi, Kab. Bungo, dan } \\
\text { Kota Sungai Penuh }\end{array}$ & Kab. Kerinci, Kab. Merangin, dan \\
\end{tabular}

Sumber : Data diolah

Untuk melihat faktor-faktor yang pengaruh yang mempengaruhi pertumbuhan ekonomi dilakukan uji dengan tiga faktor yang dominan mempengaruhi pertumbuhan ekonomi wilayah yaitu Faktor Investasi, Biaya Modal dan factor Tenaga kerja, dan hasil analisis pada tabel 4 berikut :

Tabel 4. Hasil Analisis Regresi Faktor - Faktor Yang Mempengaruhi Pertumbuhan Ekonomi Wilayah Kabupaten / Kota di Provinsi Jambi tahun 2008-2013

\begin{tabular}{|c|c|c|c|c|c|c|c|c|c|c|c|}
\hline \multirow{3}{*}{ Nama Daerah } & \multirow{3}{*}{$\mathrm{R}$} & \multirow{3}{*}{$\begin{array}{c}\mathrm{R} \\
\text { Squa } \\
\text { re }\end{array}$} & \multirow{3}{*}{$\begin{array}{c}\text { Sig. F } \\
\text { Chan } \\
\text { ge/ } \\
\text { alfa }\end{array}$} & \multicolumn{8}{|c|}{ Model } \\
\hline & & & & \multicolumn{2}{|c|}{$\begin{array}{c}\text { (Constan } \\
\mathrm{t})\end{array}$} & \multicolumn{2}{|c|}{ Investasi } & \multicolumn{2}{|c|}{$\begin{array}{l}\text { Biaya } \\
\text { Modal }\end{array}$} & \multicolumn{2}{|c|}{$\begin{array}{c}\text { Tenaga } \\
\text { Kerja }\end{array}$} \\
\hline & & & & $\mathrm{B}$ & Sig & B & Sig & $\mathrm{B}$ & Sig & B & Sig \\
\hline Tanjung & .98 & .978 & .032 & .01 & .92 & .32 & .15 & .59 & .04 & .45 & .06 \\
\hline Barat & $8^{\mathrm{a}}$ & & & 0 & 7 & 7 & 0 & 7 & 6 & 8 & 2 \\
\hline Tanjung Jabung & .89 & .799 & .285 & .01 & .96 & .02 & .95 & .40 & .33 & .81 & .17 \\
\hline Timur & $4^{\mathrm{a}}$ & & & 4 & 7 & 8 & 0 & 9 & 2 & 6 & 7 \\
\hline Kabupaten & .91 & .830 & .244 & .05 & .87 & .18 & .66 & .58 & .20 & .83 & .14 \\
\hline Sarolangun & $1^{\mathrm{a}}$ & & & 2 & 3 & 6 & 3 & 4 & 2 & 4 & 0 \\
\hline Kabupaten Tebo & .94 & .884 & .016 & - & 1.0 & - & .12 & .83 & .09 & .98 & .07 \\
\hline & $0^{\mathrm{a}}$ & & & .01 & 0 & .68 & 7 & 8 & 6 & 8 & 6 \\
\hline & & & & 6 & & 9 & & & & & \\
\hline
\end{tabular}

Sumber: Data olahan

Dari hasil analisis Tipologi Klasen untuk hasil perhitungan laju pertumbuhan ekonomi kabupaten /Kota di Provinsi Jambi Periode tahun 2008 -2013 Kabupaten Tanjung Jabung dan Kota Jambi berada Pada Kuadran I, (Daerah yang maju dan tumbuh pesat) Hasil sesuai dengan hasil analisis dan keadaan dilapangan, dimana pada kedua wilayah tersebut memiliki laju pertumbuhan ekonomi PDRB Perkapita yang lebih tinggi dari rata-rata laju pertumbuhan ekonomi Perkapita Provinsi Jambi. Selain itu pada daerah ini sektor konomian 
telah terkelola secara baik dan memberi dukungan yang tinggi terhadap pertumbuhan ekonomi wilayah serta pertumbuhan ekonomi Provinsi Jambi.

Kabupaten Tanjung Jabung Timur berada pada Kuadran II ( Daerah ini tergolong kedalam daerah maju tapi tertekan), hal ini dikarenakan pada daerah ini laju pertumbuhan ekonomi masih rendah bila dibandingkan laju pertumbuhan rata-rata di Provinsi Jambi tetapi kontribusi PDRB Perkapita lebih besar dari pada kontribusi rata-rata PDRB Perkapita Provinsi Jambi. Hasi analisis ini sesuai dengan kenyataan dilapangan dimana pada daerah Kabupaten Tanjung Jabung Timur Pemasukan utama dan terbesar untuk pertumbuhan ekonomi bersumber dari minyak bumi dan gas alam. Sedangkan Sektor-sektor perekonomian lainnya belum memberi kontribusi yang maksimal bagi pertumbuhan ekonomi wilayah tersebut.

Pada kuadran III (Daerah yang berkembang cepat ) terdapat daerah Kabupaten Muaro Bungo, Sarolangun, Batang Hari dan Muaro Jambi. Pada Kabupaten-kabupaten ini kontribusi ke sembilan sektor perekonomian mulai dari pertanian, pertambangan dan galian, perdagangan, angkutan dan lainnya masih mempunyai peluang yang besar untuk dikembangkan, tapi pada periode tahun 2008-2013 tersebut, kontribusinya relatif besar tetapi belum maksimal bagi pertumbuhan ekonomi wilayah kabupaten. Tapi bila dilihat dari pertumbuhan rata-rata setiap tahunnya. Pada periode dari tahun 2008-2013 pertumbuhan ekonominya selalu mengalami perkembangan begitu pula dengan kontribusinya terdapat pertumbuhan ekonomi Provinsi Jambi.

Sedangkan pada daerah yang berada pada Kuadran IV (Daerah Relatif Tertinggal). terdapat 3 wilayah yaitu Kabupaten Merangin, Kabupaten Kerinci dan Kabupaten Tebo. Kabupaten-kabupaten ini digolongkan ke dalam daerah yang relatif tertinggal. Penetapan imi dikarenakan pada ketiga wilayah ini pertumbuhan ekonominya masih rendah dan lebih rendah bila dibandigkan dengan pertumbuhan ekonomi rata-rata Kabupaten/kota yang ada di Provinsi Jambi. Hasil pengujian dengan menggunakan analisis Tipologi Klasen ini sesuai juga dengan kenyataan yang di temui dilapangan dimana pada wilayah-wilayah tersebut daerah

yang memiliki sumberdaya alam yang besar tetapi pengelolaannya masih terbatas sehingga bontribusinya kecil terhadap pertumbuhan ekonomi wilayah. Salah satu keterbatasan yang pling besar yang ada pada daerah tersebut yaitu infrastruktur pendukung yang belum memadai, serta letak geografis letak wilayah serta komplik dengan kawasan Taman Nasional. 
shingga sumber-sumber pertumbuhan ekonomi penyumbang PAD masih belum bisa terkelola dengan optimal. Sehingga pada saat ini pemerintah daerah khususnya di Kabupaten Merangin, Kabupaten Kerinci dan Kabupaten Tebo masih terfokus pada pembangunan infrastruktur pendukung serta aktif mencari alternatif sumber -sumber pemasukan Pendapatan Asli Daerah.

Dari uji Regresi dan uji t statistik untuk melihat pengaruh variabel Infestasi, Biaya Modal dan Tenaga Kerja terhadap pertumbuhan ekonomi wilayah Kabupaten/ kota di Provinsi Jambi, terlihat bahwa semua variabel yang diuji memberikan pengaruh yang positif terhadap Pertumbuhan ekonomi wilayah. dimana semakin ditingkatkan jumlah Investasi Swasta, Biaya sodal dan jumlah tenaga kerja maka pertumbuhan ekonomi wilayah juga akan terpacu dan smakin meningkat.

Begitu juga dengan pengujian untuk melihat tingkat pengaruhnya dimana hampir pada semua daerah variabel yang diuji memperlihatkan pengaruh yang signifikan terhadap pertumbuhan ekonomi wilayah, terkecuali pada variabel investasi di Kabupaten Tebo masih memberikan nilai minus (-) dengan pengertian setiap dinaikan investasi akan menekan pertumbuhan ekonomi wilayah Kabupaten Tebo. Hal ini kemungkinan disebabkan pada pariode tersebut pemerintah daerah Kabupaten Tebo belum mampu menerima masuknya investasi swasta sehingga investasi yang masuk akan mendorong pengeluaran pemerintah karena harus mengembalikan pinjaman dari investasi swasta tersebut.

Fakta yang ada ini sesuai dengan prinsip Investasi dimana investasi itu dapat mamacu peningkatan pertumbuhan ekonomi, dan hasilnya dari kegiatan Investasi juga bersifat jangka panjang dan tidak dapat dinikmati dalam waktu yang singkat. Hasil studi ini memperkuat teori yang dikemukakan oleh Rostow dan R.A Musgrave, yang menghubungkan investasi pemerintah dengan tahap-tahap pembangunan ekonomi. Pada tahap awal parkembangan ekonomi, menurut mereka rasio investasi pemerintah terhadap pendapatan msional relatif besar. Hal itu disebabkan oleh karena pada tahap ini pemerintah harus menyediakan berbagai prasarana seperti pendidikan, kesehatan, dan prasarana transportasi.

\section{KESIMPULAN}

Hasil penelitian ini menggambarkan bahwa pendapatan daerah/Produk Domestik Regional Bruto Kabupeten/kota di Provinsi Jambi periode tahun 2008 - 2013 terlihat adanya perbedaan tingkat pertumbuhan ekonomi antar daerah, Adapun Faktor - faktor penyebab 
terjadinya ketimpangan pendapatan antar wilayah ini karena adanya perbedaan Potensi yang dimiliki, letak Geografis, Sumber Daya Alam dan Sumber Daya Manusia.

Dari pengujian uji dengan menggunakan metode Tifologi Klassen untuk melihat ketimpangan pendapatan wilayah di Provinsi Jambi, didapati pola-pola sebagai berikut Kuadran I daerah maju dan tumbuh yaitu Kota Jambi dan Kabupaten Tanjung Jabung Barat, Kuadran II daerah maju tapi tertekan Kabupaten Tanjung Jabung Timur, kuadran III daerah yang berkembang cepat terdapat Kab. Muaro Bungo, Sarolangun. Muaro Jambi dan Kabupaten batang Hari, Kuadran IV daerah relatif tertinggal. terdapat 3 wilayah yaitu Kabupaten Merangin, Kerinci dan Kabupaten Tebo. Begitu pula hasil yang didapati setelah dilakukan Regresi menunjukan bahwa kontribusi dari variabel yang di uji seperti variabel Investasi, Biaya Modal dan Tenaga Kerja terhadap pertumbuhan ekonomi wilayah di empat kuadran tersebut sangatlah sebesar. Dan memperlihatkan pengaruh yang significan terhadap pertumbuhan ekonomi ke empat wilayah sampel.

\section{SARAN}

Dengan adanya penelitian ini diharapkan Pemerintah Daerah Provinsi Jambi khususnya dan Pemerintah Kabupaten/Kota yang ada di Provinsi Jambi. saling bekerja sama untuk mengembangkan serta mengelola potensi-potensi wilayah yang dimiliki, sehingga pengelolaan potensi tersebut akan semakin maksimal dan dapat memberi kontribusi yang besar bagi pertumbuhan ekonomi di wilayah tersebut.

\section{DAFTAR PUSTAKA}

Ahmad, Erni,2002, Petumbuhan dan Pemerataan Pembangunan Ekonami Regional, Karya Ilmiah,Jurnal Manajemen dan Pembangunan

Amir, amri,2007, Pembangunan dan Kualitas Pertumbuhan Ekonomi Dalam Era Globalisasi ( Teori Masalah dan Kebijakan ), Biografika, Bogor

Ananta, 1997, Ciri Demografis KUALITAS Penduduk dan Ekonomi, Lembaga Demografi FE - UI, Jakarta

Anonim, UU No 22 tahun 1999 tentang Pemerintah Daerah, Rineka Cipta, Jakarta

Anonim, UU No 25 tahun 1999 tentang Perimbangan Keuangan Pusat dan Daerah, Rineka Cipta Jakarta. 
Arsyad, L, 1999, Pengantar Perencanaan dan Pembangunan Ekonomi Daerah, BPFE Universitas Gajah Mada; Yogyakarta

Arsyad,L,1992,Ekonomi Pembangunan, STIE - YKPN, Yogyakarta

Aswandi, H dan Kuncoro, Mudrajat. 2002. Evaluasi Penetapan Kawasan Andalan : Studi Empiris di Kalimantan Selatan 1993 -1999. Jurnal Ekonomi dan Bisnis Indonesia diakses pada tangga120 Oktober 2012.

Jhingan, ML,1999, Ekonomi Pembangunan dan Perencanaan, PT Raja Grafindo Persada,Jakarta

Manurung M, Raharja P, 2001, Teori Ekonomi Makro,Fakultas Ekonomi UI, Jakarta

Naaluddin, 2001, Potensi Dana Perimbangan Pada Penerimaan Daerah di Provinsi Jambi, Universitas Gajah Mada,Yogyakarta

Riani, Eva,2011, Analisis Faktor Penentu Perrtumbuhan Ekonomi Dan Hubungannya Dengan Indeks Pembangunan Manusia Kabupaten Bungo Periode 2000-2010,Unja, Jambi

Roy El, 2009, Jurnal pembangunan dan kemiskinan.pdf diakses pada. tanggal 26 Desember 2012

Rustiadi E, saefulhakim S, Panuju D. R. 2009, Perencanaan dan Pengembangan Wilayah, Crespent Press dan Yayasan Obor Indonesia. Jakarta

Sjfrizal, 2008. Ekonomi Regional. Teori dan Aplikasi. Badouse Media. Padang Sumatera Utara

Sukirno, Sadono, 1999, Ekonomi Pembangunan, LPFE-UI, Jakarta

Tarigan, Robinson.2005, Perencanaan Pembangu.nan Wilayah Edisi Revisi, Bumi Aksara,Jakarta

Tarigan, Robinson.2009, Ekonomi Regional ( Teori dan Aplikasi ) Edisi Revisi, Bumi Aksara,Jakarta

Todero,Michael P dan Stephen C. Smith, 1994,Pembangunan Ekonomi di Dunia ke Tiga, edisi kedelapan, Erlangga, Jakarta

Wijakso, Eko, 2010, Analisis Pertumbuhan Ekonomi Kabupaten Bungo,Unja, Jambi. 